\title{
CHEMISTRY VS ECOLOGY
}

\author{
Acad., prof. Gheorghe Duca \\ Presentation for International Conference "Ecological Chemistry" \\ Chisinau, March 2,3 2012
}

Dedicated to the memory of my father Grigore Duca and my mentor Alexei Sytchiov

"La vie - c'est un procédé chimique" Antoine-Laurent Lavoisier

\begin{abstract}
"Chemistry versus Ecology" - this report title has not been chosen by chance. An average human and even sometimes a scientist is sure that Chemistry and Ecology are opposite to each other. But is it true indeed? To answer this deep question, first of all, the detailed definitions are to be given.
\end{abstract}

What is Chemistry? It is the science about chemical reactions, but also about the composition, structure and chemical properties of the substance. The aphorism given above proves chemistry to be a fundamentally important science, which studies the matter surrounding us. However, along with the very significant progressive constituent (new technologies and methods) chemistry has a strong negative impact that is manifested through the destruction of the environment by pollution. In addition, the fight between

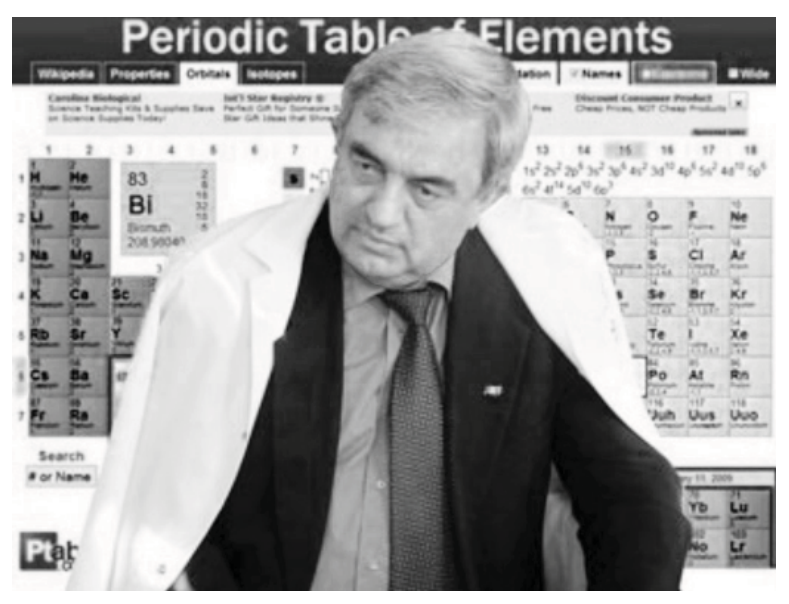
Chemistry and Ecology is considered inevitable, because any chemical substance, when its maximum admissible concentration is reached, can become a matter of serious environmental concern. In this case, a question appears: how this problem is to be faced?

Ecology is the main scientific area dealing with the problem mentioned above. Everyone knows that it is ecology that detects and warns about the environmental problems. But what does Ecology mean? The definition is the following: ecology is a science, which studies the influence of living organisms to each other and their natural environment (by Ernst Haeckel). Ecology emerged as a distinct discipline at the turn of the 20th century; the relationship between a living organism and its environment had been explained in 1843 by German chemist Justus von Liebig, taking as an example the relations "plant-soil". However, the notion "ecology" is much older, originating from the era of ancient thinkers. The first "ecologist" has been considered Aristotle or perhaps his student, Theophrastus (the latter has described the interrelationships between animals and their environment as early as in the 4th century B.C.).

Nowadays, when practically all the scientific fields overlap with each other, many interdisciplinary areas of ecology appeared. It should be noted that the current difficult ecological situation caused the appearance of the following areas: geographical ecology, physics of the environment, mathematical ecology, genetic ecology, spiritual ecology and many others. Why do so many sciences contact with ecology? Probably because ecology examines the most important phenomenon - the interaction between living organisms and the environment they live in, this notion meaning to an even greater extent healthy lifestyle, a form of friendly relations, a process of purification, the actions, which are opposite to pollution. As soon as these problems can have different impacts, the more complex approach is needed.

Coming back to the topic of the apparent opposition of chemical and ecological studies, the attention should be focused on the sciences which appeared on their border. The most important of them are:

- Ecological Chemistry that studies processes influencing formation of environmental chemical composition, adequate for the biological value of habitation.

- Chemical Ecology that is concerned with the study of chemical substances involved in the interactions of different living organisms.

- Environmental Chemistry that studies chemical and biochemical phenomena that occur in the environment.

- Green Chemistry that promotes the development of the products and processes that minimize the use and generation of hazardous chemicals. 
Ecological chemistry is developing quite intensively in recent years at the scientific and educational level. The worldwide known Universities and even colleges had set up the departments to educate the young experts in Ecological Chemistry. Many institutions in the USA, Canada, Germany, Sweden, Norway, Poland, Russia, Kazakhstan, Ukraine, Belarus, China, South Africa and many other countries are based on chemical knowledge as the main scientific priority in solving countries' environmental problems.

A prodigious scientific activity in ecological chemistry has starter about three decades ago. Then, in the 80s of the past century, on the border between chemistry and ecology a new direction called ecological chemistry has emerged. It came to reveal the chemical aspect of environment interaction with living organisms. The ecological chemistry has found supporters and promoters in different countries. This fact led us to organize in 1985 the First International Seminar on ecological chemistry in Chisinau. In 1992, the Department of Industrial and Ecological Chemistry has been set up at the Faculty of Chemistry and Chemical Technology of Moldova State University, being the first one in Moldova specialized in ecological chemistry and environmental protection, which began to prepare doctoral students in the Environmental Protection and Rational Use of Natural Resources areas.

The first textbook on ecological chemistry was edited in 1994 and subsequently translated in three languages. In 1991, the Research Centre of Applied and Ecological Chemistry (RCAEC) was established, comprising four scientific laboratories. The research performed at the department, at the RCAEC's laboratories, was dealing with the chemistry and technology of industrial processes and treatment of water and wastes and was crowned with important elaborations, such as:

- Oxidation theory of water chemical self-purification process and of seasonal dynamics of natural waters redox-state;

- Theory of nitrogen compounds transformations with the support-immobilized microorganisms;

- Theory of the redox-state of the environment;

- Methods of physical-chemical and biochemical treatment of solid and liquid wastes;

- Inhibition methods of $\mathrm{N}$-nitrosamines formation using reductons;

- Mechanisms of catalytic and photochemical oxidation of organic compounds with oxygen, hydrogen peroxide and free radicals.

The 20th anniversary of the department's formation is marked this year. During its growth and development, the department staff has been making the Chemistry students think "ecologically". Actually, among the brightest realizations of the department is the significant number of students and publications. More than 20 monographs and manuals, 11 didactic materials for theoretical courses, 15 handbooks for laboratory works and approximately 500 scientific articles in the field of ecological chemistry and environmental protection were published; 130 patents for inventions were obtained. The titles of the main scientific monographs are highly suggestive, regarding the complexity and actuality of the problems discussed. They are the following: "Environmental redox-processes" (2001), "Ecological Audit"(2002), "Combustion technologies and reducing the air emissions" (2002), "Natural waters' pollution and self-purification processes" (2002), "Environmental issues in power engineering" (2003), "Ecologically pure wine industry" (2004), "The hydrochemistry of small rivers" (2004), "Environmental economy" (2005), "Wastes management" (2006), "The fundamentals of winery wastes treatment" (2007), "Ecological chemistry of nitrates, nitrites and N-nitrosamines" (2009), "ENOXIL - an ecological preparation for plant protection" (2010), "Secondary wine products" (2011).

Only the professional staff is working at the department (28 persons), including academician - 1, professors - 6 , associate professors -8 , superior lecturers -8 , assistant lecturers -5 . The number of students is the following: license students (courses I, II, III) - 234, master students -69 , doctoral students -8.120 foreign students graduated from the department during the period of its activity as well. It should be mentioned that in 2008-2009 academic year the specialty entitled Ecological chemistry and environmental protection (master and doctorate studies) at the Department of Industrial and Ecological Chemistry of the State University of Moldova has been introduced.

Thus, the department had played an important role in the development of ecological chemistry and environmental protection in the Republic of Moldova and reached a very honorable position in this scientific area.

The educational aspect of Ecological Chemistry in Moldova is represented not only by the State University of Moldova (SUM), but also by the University of the Academy of Sciences of Moldova, "A. Russo" State University, Bălți and Tiraspol State University, where not only the special courses are delivered, but the research laboratories and entire research centers work as well.

Nevertheless, the fundamental research in the ecological chemistry area is carried out mainly in two major institutions - the Research Center Applied and Ecological Chemistry of SUM and the Institute of Chemistry of ASM. There are 6 main research directions:

1. Ecological Chemistry of Water

2. Ecological Chemistry of Atmosphere

3. Ecological Chemistry of Soil

4. Ecological Chemistry of Wastes

5. Ecological Chemistry and Renewable Energy 


\section{Ecological Chemistry and Healthy Lifestyle.}

\section{Ecological Chemistry of Water}

A bright example of Ecological Chemistry promoting is the state program entitled "Water Quality Management and Research", where the chemistry and ecological condition of water sources have been studied under the several research projects.

Starting with the fundamental research in this direction, we will pass to the projectentitled "SELF PURIFICATION OF SURFACE WATER" supervised by dr. Viorica Gladchi that deals with the Catalytic redox processes in natural water. Analyzing the chemical composition of water, we can conclude that it includes the substances featuring the required properties to enable the running of redox-catalytic processes: oxidative equivalents $\left(\mathrm{O}_{2}, \mathrm{H}_{2} \mathrm{O}_{2}\right.$, etc..), reductants $\left(\mathrm{DH}_{2}\right.$ and catalysts $\left(\mathrm{M}^{(\mathrm{n}-1)+} / \mathrm{M}^{\mathrm{n}+}\right)$.

The reducers are among the participants in the redox process in water: autochthonous substances - resulted from metabolism and decomposition of hydrobionts; allochthonous substances - substances that penetrate the aquatic environment together with atmospheric precipitates or wastewater. Copper and iron are metals having the great importance for redox transformations and can be found in water in catalytic concentrations.

The transformations of nitrogen compounds were studied by Prof. Maria Gonta under the project "NITRATES, NITRITES AND NITROSOAMINES". The scheme of oxidation and reduction of nitrites and nitrosoamines in water, food and living organisms was elaborated. The mechanism of nitrites reduction in the presence of various antioxidants, that caused the decrease in oncology maladies at people of different age was proposed. This research was carried out in cooperation with the Nebraska Cancer Center (dr. Irina Stepanov, USA).

Under the project "PSEUDO JAHN-TELLER INSTABILITY OF HIGH- SYMMETRY PROTONATED WATER CLUSTERS" leaded by m.c. Ion Geru, the new experimental data on the different energy of $\mathrm{H}_{2 n+1} \mathrm{O}_{n}^{+}$systems decay, and those referring to the spatial dimensions of non-homogenates in the water hydrogen bonds' network were obtained. This fundamental research has a prospective application, especially in water purification from heavy metals. The brightest result of this project is that the 65th water anomaly has been found - it consists in the diffusion indices increase in the case of $\mathrm{Ca}^{2+}$ ions concentration increase.

"SYNTHESIS AND STUDY OF PHOTOSENSIBILIZATORS ON THE BASE OF FURANE-CARBOXILIC ACID, FUROCEN-PORFIRINE, QUINOLINE-PIRIDINE AND IMIDAZOLINE DERIVATIVES" - the project, conducted by acad. Constantin Turtă is aimed to elaborate the new synthesis methods of substances mentioned above and also to obtain and to make a deep physical-chemical analysis of Fe- and Ti-nanoparticles. This work is a spin off in the new photocatalytical method to obtain hydrogen from water.

"THERMODYNAMIC ANALYSIS OF ALUMINUM HETEROGENEOUS SPECIATION IN NATURAL WATERS", supervised by the Institute of Chemistry ASM, dr. hab. Igor Povar, has the following results: the new type of diagrams based on graphical and computerized methods, which quantitatively describe the distribution of soluble and insoluble, inorganic and organic, monomeric and polymeric aluminum species in heterogeneous aquatic systems was elaborated. The factors influencing the distribution of soluble and insoluble aluminum species in aquatic systems were also analyzed.

„MONITORING OF PHOSPHORUS FORMS IN NATURAL WATERS FOR THE ENTIRELY SYSTEM WATER-PARTICULATE MATERIALS-BOTTOM", the project supervised by the Institute of Chemistry ASM, dr. hab. Vasile Rusu, reached the following goals. Water samples have been collected from 46 springs in Ialoveni region. The physical-chemical composition of water has been determined, which served as basis for the estimation of the water quality. $7 \%$ (3 springs) of water are in compliance with drinking water status, $35 \%$ (16 springs) of water has the hardness between 7 and $10 \mathrm{mg} / \mathrm{dm}^{3}$ (acceptable for consumption), 5 of those 16 springs are polluted with nitrates. 58\% (27 springs) contain hard water and 37\% (17 springs) have shown a mineralization higher than $1000 \mathrm{mg} / \mathrm{dm}^{3}$.

„THE ROLE OF THE DNIESTER RIVER'S TRIBUTARIES IN THE FORMATION OF ITS CHEMICAL COMPOSITION AND THE SPRINGS OF DNIESTER BASIN AS NATURAL ECOSYSTEMS AND DRINKING WATER SOURCES" - the project, directed by the Ministry of Ecology and the State University of Moldova (dr. Elena Bunduchi, dr. Nelly Goreaceva), has as the main purpose to determine the sources of toxic chemical substances flow in Dniester river and to elaborate several protective measures (including the most dangerous areas in the list of those protected by State). The water quality of Dniester was estimated by oxygen content, which confirmed the permanent pollution of water. The class of the water quality degraded from I and II - very clean water (portions of the streams near Dubasari up to the capture point, located upstream the mouth of Byc river) to class III - moderately polluted water (downstream the mouth of Byc river and upstream the mouth of Botna river) and class IV - polluted water downstream the mouth of Botna river.

The project entitled „THE HYDRAULIC BALANCE AND BIOGEOCHEMISTRY OF GROUNDWATER IN THE RURAL AREAS OF THE REPUBLIC OF MOLDOVA", headed by the Academy of Sciences of Moldova, the Institute of Geology and Seismology, dr. Constantin Moraru, works on the elaboration of the model hydrogeochemical map of groundwater in the Central-Eastern zone and on obtaining the standard data on the groundwater quality. 
The project „GEOINFORMATIONAL SUPPORT FOR HYDROLOGIC RISK ESTIMATION IN PRUT RIVER BASIN", implemented by the Institute of Ecology and Geography of the Academy of Sciences of Moldova, dr. Nicolae Boboc (Institute of Ecology and Geography) and dr. Viorel Bostan (UTM), aims to create a cartographic database in digital format and to use software (HEC-RAS, HEC-GeoRAS, ArcHydro) for hydrologic risk estimation.

The biodiversity study is represented by the project entitled „BIODIVESITY AND ECOLOGICAL SUCCESSIVES OF AQUATIC ECOSYSTEMS OF PRUT RIVER'S INFERIOR SECTOR” leaded by Prof. Elena Zubkov. The important qualitative and quantitative indices of aquatic ecosystems will be obtained, and also the antropic influence on biocoenosis functioning will be evaluated. The investigations referring to the role of some chemicals and nutrients on the production-destruction processes in Prut river will be done.

“ASSESSMENT OF CHILDREN MORBIDITY IN PRUT ZONE BY HYDRICALLY TRANSFERED DISEASES AND ELABORATION OF PREVENTION MEASURES" - in the framework of the project of the Ministry of Health, National Center of Public Health, dr. hab. Grigore Friptuleac, the current state of Prut river was analyzed and the concrete indices of water's chemical composition and pollution degree, dependent on the seasons, were obtained.

Water treatment is one of the main branches of ecological chemistry of water. This area is represented by a sound number of research projects. They are as follows:

"EFFICIENT USE OF AUTOCHTHONOUS ACTIVE CARBON IN THE WATER TREATMENT PLANT OF "APĂ-CANAL CHIŞINĂU”, headed by the Institute of Chemistry of Academy of Sciences of Moldova, dr. hab. Tudor Lupaşcu, aimed to determine the physical-chemical properties of autochthonous active carbon, to make a clear classification of the adsorbents in accordance with their adsorption parameters, to find those pollutants that should be eliminated and to establish the optimal methods for their removal.

„TEXTILE WASTEWATER TREATMENT FROM TEXTILE COLORANTS” (supervisors: the Ministry of Ecology, State University of Moldova, dr. hab. Maria Gonța) aimed to elaborate the new efficient methods of reducing the concentration of textile colorants in the presence of cationic and anionic surfactants using the combination of coagulants and oxidizers for water treatment.

“ANAEROBIC TREATMENT OF THE DISTILLERY AND WINERY WASTEWATER WITH OBTAINING OF BIOGAS AND USEFUL PRODUCTS" - in the framework of this project, directed by the Ministry of Ecology, State University of Moldova, dr. Victor Covaliov, the new technical solutions for water treatment have been elaborated, the new additives for stimulation of anaerobic fermentation and methanogenesis of bio-active substances, obtained from agro-industrial wastes were tested; a new method of methanogenic synthesis of vitamin $\mathrm{B}_{12}$ in the contents of sludge resulted from the anaerobic wastewater treatment; a new method of biomethane concentration increase in biogas have been proposed.

The project "PHYSICAL-CHEMICAL TREATMENT AND CONDITIONING OF NATURAL WATERS", supervised by dr. Olga Covaliova, has the following development purpose - to elaborate the cheaper treatment technologies; to reach efficient water treatment; to ensure the reuse of treated water. A new method of underground waters treatment with the removal of hydrogen sulfide has been elaborated. The combined method and integrated reactor have been developed for the degradation of benzothiazoles and their mineralization to simple molecules, such as water, carbon dioxide, etc. It was found that under the UV-irradiation, photo-degradation of benzothiazoles runs efficiently, but rather slow. Therefore, it was proposed to combine photo- and biodegradation methods, which is an energy-saving and efficient method.

The results of the project, headed by dr. Oleg Bogdevici, entitled "WATER QUALITY CONTROL AND MONITORING" are the validation of analytical methods for the determination of priority monitoring substances, in accordance with the Water Framework Directive; the determination of the spectrum of toxic organic pollutants from potential pollution sources at urban and rural areas of Republic of Moldova; the creation of the database of groundwater potable sources - more than 3000 hydrogeological boreholes were included.

\section{Ecological Chemistry of the Atmosphere}

Even if this is not the first priority area of ecological research in Moldova, some research have been carried out in this field. For example, the theoretical study, carried out by dr. Natalia Gorincioi „RADICAL REACTIONS IN THE ATMOSPHERE", had to examine the diversity of hydroxyl radical reactions in the atmosphere, the legitimacies of photochemical smog and PAN compounds formation, both of them being severe irritants to eyes, and having phytotoxic effect. The presence of the strongly reduced carbon $\left(\mathrm{CH}_{4}\right)$ in a strong high-energy oxidant (stratosphere: $\mathrm{O}_{3}, \mathrm{O}_{2}$, hv) has been determined; consequently, methane at high altitudes increases the concentrations of hydroxyl and water radicals. The ways of PAN (peroxyacetylnitrates) decomposition were also studied (reverse process, photolysis, thermal degradation, reaction with $\mathrm{OH}-$ radicals).

The project entitled "EXCESSIVE POLLUTION OF THE ENVIRONMENT WITH HEAVY METALS LEAD, CADMIUM AND SULPHATES”, directed by Prof. Alexandru Teleuța, aimed to investigate the negative impact of increased lead content in the atmosphere. It has been established that heavily polluted air with $\mathrm{SO}_{2}\left(0,3-0,5 \mathrm{mg} / \mathrm{m}^{3}\right)$ 
(in regions - Rezina, Râbnița, Căușeni Tighina, Tiraspol and Cahul) increases the withering process of such tree species as oak, willow and pine - Tilia microphyla and Pinus nigra. The species of lichen sensitive to pollution - Usnea hirta, Peltygera canina, Ramalina fraxinea have disappeared from these areas.

\section{Ecological chemistry of soil}

Soil is a very important natural value of Moldova. The food safety, export of agricultural products, welfare and ecological situation of the country depend mainly on the condition and production capacity of the soil. The current state of the soil layer is unsatisfactory (50\% of agricultural land) and even critical (about 10\%). The applied research "SOIL'S CONDITION AND PROTECTION", conducted by acad. Andrei Ursu, acad. Serafim Andrieş and Prof. Boris Boincean aims to keep the fertile soil layer and to minimize the surface and ground water pollution with nutrients and plant protection substances. The set of measures implemented by the "Nicolae Dimo" Institute against soil erosion phenomena, ensures the soil loss reduction below the allowable $5 \mathrm{t} /$ ha limit. The economic effect is $100-650$ euro / ha. The application of phytoameliorators (4 years cultivation of the perennial herbs on leached chernozem and the ordinary vetch with green fertilizers) led to the increasing of the reserves of nitrogen and organic substances in soil, partial remediation of soil characteristics (structure, favorable agronomic aggregates' hydrostability, reducing the bulk density), significant increase of agricultural production. Experimentally it was established that the application of the environmentally friendly agricultural practices lead to the remedy of soils' biological properties by the increase of the invertebrates' biomass and the number of species, increase of microbial biomass, intensification of enzymatic activity, improvement of biodiversity level.

\section{Ecological chemistry of wastes}

The wastes include all the objects or substances which the holder discards, intends to discard, or is legally obliged to discard, i.e. all the unwanted or useless material. Wastes may be classified according to their origin, their properties, how hazardous they are, and how they may be sorted, recovered or treated.

If we talk about the autochthonous wastes, the grape seeds, as well as the other secondary products of wine industry should be firstly considered. Such industrial wastes contain the increased tannins amounts, which represent a series of natural compounds with polyphenolic structure. The interest towards these compounds has appeared due to their antioxidant properties, i.e. these compounds trap the free radicals, thus protecting the human organism from various diseases, such as cancer and cerebral ictus. The majority of enotannins are soluble in ethylic alcohol and are insoluble in water. This circumstance hindrances the utilization of enotannins in various fields, including pharmaceutics. The specialists of Ecological Chemistry Laboratory of the Institute of Chemistry, directed by prof. Tudor Lupaşcu, have elaborated and patented a procedure for hydrosolubilization of enotannins. Using the method of mass spectrometry, it was found that the procedure consists in breaking of catechol polymers in enotannins. As the result of this procedure, a new product was obtained, formed from monomers, dimers, trimers of catechol, polydentate carboxylic acids, peroxidic compounds etc. Microbiological, pharmacological and toxicological studies, performed under the project „NEW PREPARATIONS FROM GRAPE SEEDS FOR MEDICINE, VETERINARY AND AGRICULTURE” and „EVALUATION OF ACTIVITY OF MEDICINAL AND AGRICULTURAL PREPARATIONS OBTAINED ON THE BASIS OF THE BIOLOGICALLY ACTIVE COMPOUND ENOXIL IN CLINICAL AND FIELD TRIALS" in the frames of the State Program „PROCESSING AND UTILIZATION OF WINERY WASTES AND OBTAINING OF NEW COMPOUNDS" directed by acad. Gh. Duca, demonstrated that Enoxil is not toxic and possesses the significant antifungal and antibacterial properties. On the basis of the active compound Enoxil, the preparations Enoxil-M and Enoxil-A were elaborated and tested under the clinical and field conditions. The field tests showed that the preparation Enoxil-A increases the resistance of agricultural cultures by $60 \%$ towards the action of root rot and of vine - by two folds, as well as towards grey rot. Clinical trials of the medicinal preparations Enoxil-M produced at „Farmaco” enterprise demonstrated a positive effect in the treatment of diseases induced by fungi and bacteria, of plagues provoked by thermal and surgical lesions. The results indicated above refer to the State Program, which have been realized during the period 2004-2008 and had a very important objective of efficient management of the wastes originated from wine industry and consequently from the autochthonous raw material. In the framework of this State Program, certain studies had been carried out:

„ANAEROBIC TREATMENT OF WINERY WASTEWATERS WITH BIOGAS OBTAINING AS AN

ALTERNATIVE SOURCE OF HEAT AND ELECTRIC ENERGY" headed by dr. V. Covaliov; „NEW TECHNOLOGIES OF NEW REDUCTONS OBTAINING FROM THE WINERY WASTES”, directed by dr. hab. M. Gonța;

„NEW MEDICINAL, VETERINARY AND AGRICULTURAL PREPARATIONS ON THE BASIS ON THE

GRAPE SEEDS AS RAW MATERIAL”, headed by dr. hab. T.Lupaşcu; „ELABORATION AND TRANSFER OF OILS OBTAINING TECHNOLOGY FROM THE WINERY

WASTES”, supervised by dr. E. Iorga;

„ELABORATION OF THE TECHNOLOGICAL COMPLEX OF CONCENTRATED ANTHOCYANINES

PRODUCTION FROM GRAPES", headed by dr. C. Bodean; 
„ELABORATION OF TECHNOLOGICAL REGULATIONS FOR TARTARIC ACID AND ITS DERIVATIVES OBTAINING USING THE AUTOCHTHONOUS RAW MATERIAL”, directed by dr. hab. M. Gonța and dr. A.Mereuța;

"MEDICINAL AND AGRICULTURAL PREPARATIONS OBTAINED ON THE BASIS OF BIOLOGICALLY ACTIVE SUBSTANCE ENOXIL UNDER THE FIELD CONDITIONS", directed by dr. hab. T. Lupaşcu;

„ELABORATION OF GRAPE SEEDS TREATMENT BIOTECHNOLOGY FOR OBTAINING OF OILS

WITH HIGHLY DETERMINED QUALITY PROPERTIES", headed by dr. V. Țuțuc;

„THE USE OF THE ALCOHOL INDUSTRY WASTES”, supervised by dr P. Parasca;

„PHOTOCATALYTICAL TREATMENT OF THE DISTILLERY GRAINS FOR INTENSIFICATION OF

BIOGAS GENERATION AND NATURAL FERTILIZERS' PRODUCTION", headed by dr. V. Covaliov; „PILOT PLANT AND TECHNOLOGICAL REGIMES FOR THERMAL NEUTRALISATION OF TOXIC SEDIMENTS CONTAINING PRUSSIAN BLUE", headed by dr. E. Obadă.

If we consider the wastes classified as noxious and hazardous, much attention should be paid to "NITRATES, NITRITES AND N-NITROSOAMINES STUDY". This is the title of the project, headed by the State University of Moldova, dr. hab. Maria Gonța, which studied the chemical risk and the influence of these chemical substances, belonging to the group of dangerous ones, on the environmental conditions. $\mathrm{The}^{\mathrm{NO}}{ }_{2}^{-}$reduction mechanism in the presence of inhibitors and the secondary aliphatic amines nitrosation mechanism have been proposed. It was shown that the reductants interact in a reactionary system with the formed species (at higher $\mathrm{pH}, \mathrm{N}_{2} \mathrm{O}_{3}$ is dominant), thus resulting in the reduction of nitrosating agents concentration. The ways of people exposure to NNA were revealed, including the exogenous (eating, smoking, cosmetic products, polluted air, water, industrial products) and even endogenous one (nitrosation of precursors in the gastrointestinal system).

It is to be mentioned that even if the economic costs of wastes managing are high, the money can often be saved by the efficient wastes monitoring and management, including the fees collection, modifying of vehicles, and, especially, public education. The latter is popularizing by State University of Moldova and other Universities of the country as well.

\section{Renewable energy}

For the Republic of Moldova, a country which doesn't possess such energy sources as oil and natural gas, the "RENEWABLE SOURCES OF ENERGY STUDY" (the project, supervised by the Institute of Power Engineering of the Academy of Sciences of Moldova, dr. hab. Postolache Gh.) has become a very actual research. In the framework of the project, it was established that for Moldova the following types of renewable energy sources are convenient: biomass energy, solar thermal energy, solar photoelectric energy, wind energy, hydropower. The technical potential of these types of renewable energy sources were considered, as well as the volume of energy production substituted by the renewable energy sources and the technical potential of main types of renewable energy (million tons of conventional fuel). The main applied results of the project are the following:

- two biogas plants constructed in collaboration with Dutch scientists for livestock and poultry production (Colonita);

- Installation for the use of methane from household wastes (Tintareni);

- Oil production plant from rapeseed;

- Photoelectric cell production plant that produces traditional membrane cells (Orhei);

- In 2009 the Academy of Sciences of Moldova has launched a testing ground on renewable energy sources (State Program).

- Boiler installations for straw incineration (Stefan-Voda). In order to obtain the heat energy from biomass (pressed straw), Moldagrotehnica JSC has launched the production of boilers, licensed by ALCON (capacity ranges from 30 to $750 \mathrm{~kW}$ ). These boilers can be used for heating of schools, kindergartens and other public institutions. Since 2010, Moldagrotehnica JSC also started the production of boilers for pellets (chips, sawdust and other waste) with a capacity of 17 to $75 \mathrm{~kW}$.

- Biogas reactor for wine (cognac) bards recycling. The project plant "Vinaria-Bardar" has a bioreactor of 40 $\mathrm{m}^{3}$ which uses the distillery wastes. Also other 32 wineries have similar equipment which enables the recycling of harmful discharge up to the total volume of $5 \mathrm{mln} . \mathrm{m}^{3}$.

Returning to the bio-fuel theme, the project supervised by dr. Covaliov V. should be mentioned. It is entitled „BIOGAS TECHNOLOGY IMPROVEMENT”, and aims to: finding a competitive and flexible technology to achieve high yield of biogas as an alternative energy source, reaching an efficient and energy saving biochemical treatment of wastewaters that ensure repeated use, obtaining the vitaminized sludge that can be used as a feeding additive for cattle or as fertilizers. 


\section{Ecological Chemistry and Healthy Lifestyle}

It is well-known that the current ecological situation has a strongly negative impact on the normal vital activity of living organisms. This is the reason why the direction wich connects the ecology of environment and the chemistry and biochemistry of living matter, had appeared under the name of ecological chemistry and healthy lifestyle.

Among the gravest consequences of environmental pollution on human organism are the destructive processes taking place on the cellular level, because namely they regulate the state of entire organism. One of them is considered to be the oxidative stress, which is associated with the increased production of oxidizing species or the significant decrease in the capability of antioxidant defenses. In the Republic of Moldova this problem is also studied.

The interest in plant metabolites as sources of antioxidants appeared a long time ago. Dihydroxyfumaric acid is one of the leaders, due to its potential, in the series of natural reductons. "THE OBSERVATIONS ON THE ANTIOXIDANT ACTIVITY OF NOVEL DIHYDROXYFUMARIC ACID DERIVATIVES" is the project, directed by the Institute of Chemistry of Academy of Sciences of Moldova, dr. hab. Fliur Macaev and Natalia Secara. The obtained results show that the presence in the molecules of amides or heterocyclic derivatives of additional nitrogen atoms has a negative effect on the antioxidant activity in comparison with the activity of anilide or bis-benzimidazole, benzimidazole with a free carboxyl- group which showed antioxidant activity twofold higher than the ether derivative of dihydroxyfumaric acid.

Another factor, which indicates the ecological chemistry to be very actual, modern and popular direction in the world is the number of scientific conferences and forums, dedicated to it. The organization of International symposia aimed to generalize and to exploit the experience in ecological chemistry, has become a tradition in Chisinau. The first Symposium of such kind was organized in Moldova in 1995 and brought together 150 participants. The second international symposium (2002) gathered 260 scientists from 26 countries. In the third international symposium on ecological chemistry (2005) 470 participants from 38 countries were registered. In autumn 2008 Chisinau again was hosting a major scientific forum (the fourth) on ecological chemistry. The workshop organized with the NATO support has a scope to analyze the level and quality of research in ecological chemistry in the CIS countries, those of Middle East and Western Europe, to present the new approaches and strategies referring to the technological development tolerant to the environment, to the sustainable development and capacity building, including education. Thus, researchers from 12 countries had analyzed the entire complexity of ecological chemistry problems - from pollution research to sustainable development for relevant regional and international collaboration, had discussed the increasing role of researchers in decision making on the environment in regional and international context, had elucidated the role of ecological chemistry to build the knowledge-based society in Western and Eastern Europe, USA and Arab countries. The pollution knows no national borders. It's an issue of international security. A continuation of these major events is the present one, the 5th International Conference "Ecological Chemistry - 2012", which will provide opportunities to exchange the latest ideas, to present and discuss recent results on the physical-chemical and biochemical aspects of processes occurring in the ecosystem - soil, air and water, and promising approaches for sustainable development, including engineering and modeling with social and educational implications.

A logic continuation of the achievements which have been reached in the field of ecological chemistry are the tasks that we set for the next five years:

- Development of research in the field of theory of the redox phenomena in aquatic environment.

- Study of the processes and mechanisms of oxidation-reduction, migration, accumulation, sorption of persistent organic pollutants, heavy metals, nitrogen and phosphorus compounds, surfactants, petroleum products etc. in the aquatic environment with the scope to reveal the formation principles of surface, phreatic and underground water quality.

- Elaboration of ecological sustainable technologies for natural water conditioning and industrial wastewater treatment by coagulation, flocculation, flotation, decantation, adsorption, UV radiation, oxidation-reduction using homogeneous and heterogeneous catalysts, ion exchange, etc.

- Elaboration of nanoporous catalysts on the basis of activated carbon, natural and synthetic adsorbents, transition metal oxides. Study of the structure, chemical and physicochemical properties of these catalytic supports, useful for water treatment.

- Target oriented synthesis, study of structure, magnetic and catalytic properties of coordination nanocatalysts for use in the processes of water photolysis to obtain hydrogen.

- Elaboration of chemical, physico-chemical, including electro-chemical, spectral methods of determination of toxic substances in environmental objects, food, etc.

- Elaboration of efficient methods for extraction of useful substances from agricultural secondary and waste 
products and study of the structure, chemical, physicochemical and microbiological properties of new chemical preparations.

- Target oriented synthesis of new chemical compounds from natural sources. Study of their chemical structure, chemical and physicochemical characteristics, as well as antioxidant, antifungal, antibacterial, anticancer properties, etc. in order to obtain pharmaceutical and phytochemical products for human health and plant protection.

- Gradual implementation of new production technologies oriented to low energy consumption and low waste generation.

All these goals represent real challenges for our scientific community, but we are confident that they could be turned into reality. Modern society needs our contribution and there is no other way.

Finally, I would like to express my gratitude to all Symposium participants for their presence and active participation. We do really hope that our event will bring new ideas and collaborations, new solutions and perspectives. 